\title{
Making a Mark: Process, Pattern and Change in the British and Irish Neolithic
}

\author{
Andrew Meirion Jones ๑ \& Marta Díaz-Guardamino
}

\begin{abstract}
This paper presents key results of the Making a Mark project (2014-2016), which aimed to provide a contextual framework for the analysis of mark making on portable artefacts in the British and Irish Neolithic by comparing them with other mark-making practices, including rock art and passage tomb art. The project used digital imaging techniques, including Reflectance Transformation Imaging (RTI), and improved radiocarbon chronologies, to develop a new understanding of the character of mark making in the British and Irish Neolithic. Rather than considering this tradition in representational terms, as expression of human ideas, we focus on two kinds of relational material practices, the processes of marking and the production of skeuomorphs, and their emergent properties. We draw on Karen Barad's concept of 'intra-action' and Gilles Deleuze's notion of differentiation to understand the evolution and development of mark-making traditions and how they relate to other kinds of social practices over the course of the Neolithic.
\end{abstract}

The mark-making traditions of Neolithic Britain and Ireland (c. 4050-2300 cal. BC) are spectacular and enigmatic. Despite this, they are often overlooked in traditional accounts of the Neolithic. This is especially the case for portable art, which is also largely unknown within the broader European scholarly context. The mark-making traditions of Neolithic Britain and Ireland consist of very few examples of representational images. Instead, marks of an abstract linear, curvilinear and geometric character predominate in a number of contexts: as open-air rock art; in passage tombs in Ireland, north Wales and Orkney; in the settlement architecture of the Orkney Neolithic; and on a suite of portable decorated artefacts found across Britain and Ireland.

This paper presents the results of the Making a Mark project (2014-2016), which aimed to provide a contextual framework for the analysis of mark making on portable artefacts in the British and Irish Neolithic by comparing them with other markmaking practices, including rock art and passage tomb art. This was achieved by: i) digitally documenting and analysing a suite of decorated artefacts from across Britain and Ireland and comparing both decorative motifs and practices of decoration with the recorded material from passage tombs and openair rock art; ii) using the new dates generated by Bayesian radiocarbon dating and modelling programmes (e.g. Bayliss et al. 2017; Marshall et al. 2016; Richards et al. 2016; Whittle et al. 2011) to provide firmer chronologies for the development of mark-making practices.

The combination of new digital analyses and improved radiocarbon chronologies allows us to develop a new understanding of the practices and changes associated with mark making over the course of the Neolithic.

The project used digital imaging techniques, including close-range Structure from Motion (SfM) photogrammetry and Reflectance Transformation Imaging (RTI) as a means of understanding the character of mark making in the British and Irish Neolithic. We do not discuss the methodological aspects of the project here, as they are well covered by discussions elsewhere (e.g. Jones \& Díaz-Guardamino 2019, 21-2; Jones et al. 2015). Instead, we present an overview of

Cambridge Archaeological Journal 32:3, 389-407 @ The Author(s), 2021. Published by Cambridge University Press on behalf of the McDonald Institute for Archaeological Research. This is an Open Access article, distributed under the terms of the Creative Commons Attribution licence (https:// creativecommons.org/licenses/by/4.0/), which permits unrestricted re-use, distribution, and reproduction in any medium, provided the original work is properly cited.

doi:10.1017/S0959774321000512 Received 9 Apr 2021; Accepted 7 Sep 2021; Revised 3 Sep 2021 


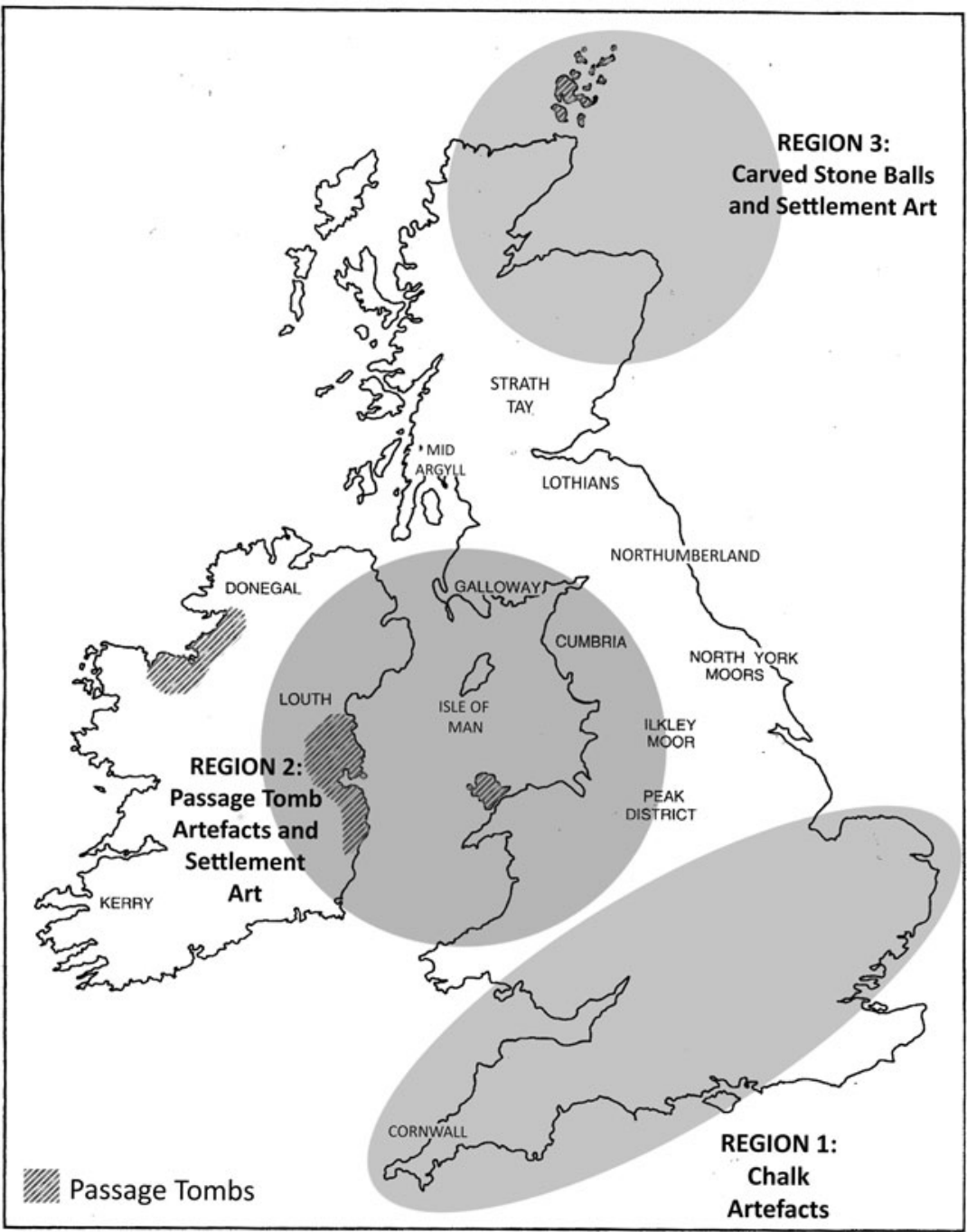

Figure 1. Study areas of the Making a Mark project. (Map: (C) Hannah Sackett.) the chronology of decorated artefacts in Neolithic Britain and Ireland and an interpretation of those chronological developments.

From a representational perspective, Neolithic mark-making traditions in Atlantic Europe appear to defy evolutionary accounts of development, being visually much simpler than many European Upper Palaeolithic or Mesolithic traditions. The lack of obvious representational images may account for the fact that Neolithic mark making in Atlantic Europe, has been frequently overlooked in wider archaeological accounts and in synthetic accounts of the Neolithic. How, then, should we understand these traditions of mark making? In the case of Britain and Ireland, rather than considering this tradition in representational terms, as an expression of human ideas, we instead pursue a relational analysis of mark making, by focusing on relations and their emergent properties. In particular, we focus on two kinds of relational material practices: the processes of marking, and the production of skeuomorphs. We adopt Karen Barad's (2007) notion of 'intra-action' and Gilles Deleuze's ([1968] 1994) allied notion of differentiation as a way of analysing the working of these two practices. Barad's work on mattering, relationality and entanglement has been previously discussed by a number of authors in archaeology and anthropology (Back Danielsson \& Jones 2020; Crellin 2020; Goldhahn 2019; Ingold 2013; 2018; Jones 2015; Jones \& Cochrane 2018; Marshall \& Alberti 2014) and the notion of intra-action is now quite a wellworn means of discussing the relationship between humans and materials; we discuss and develop this concept in the context of Neolithic mark making below. We argue that differentiation enables us to understand the evolution and development of mark-making traditions and how they relate to other kinds of social practices over the course of the Neolithic. 
Making a Mark

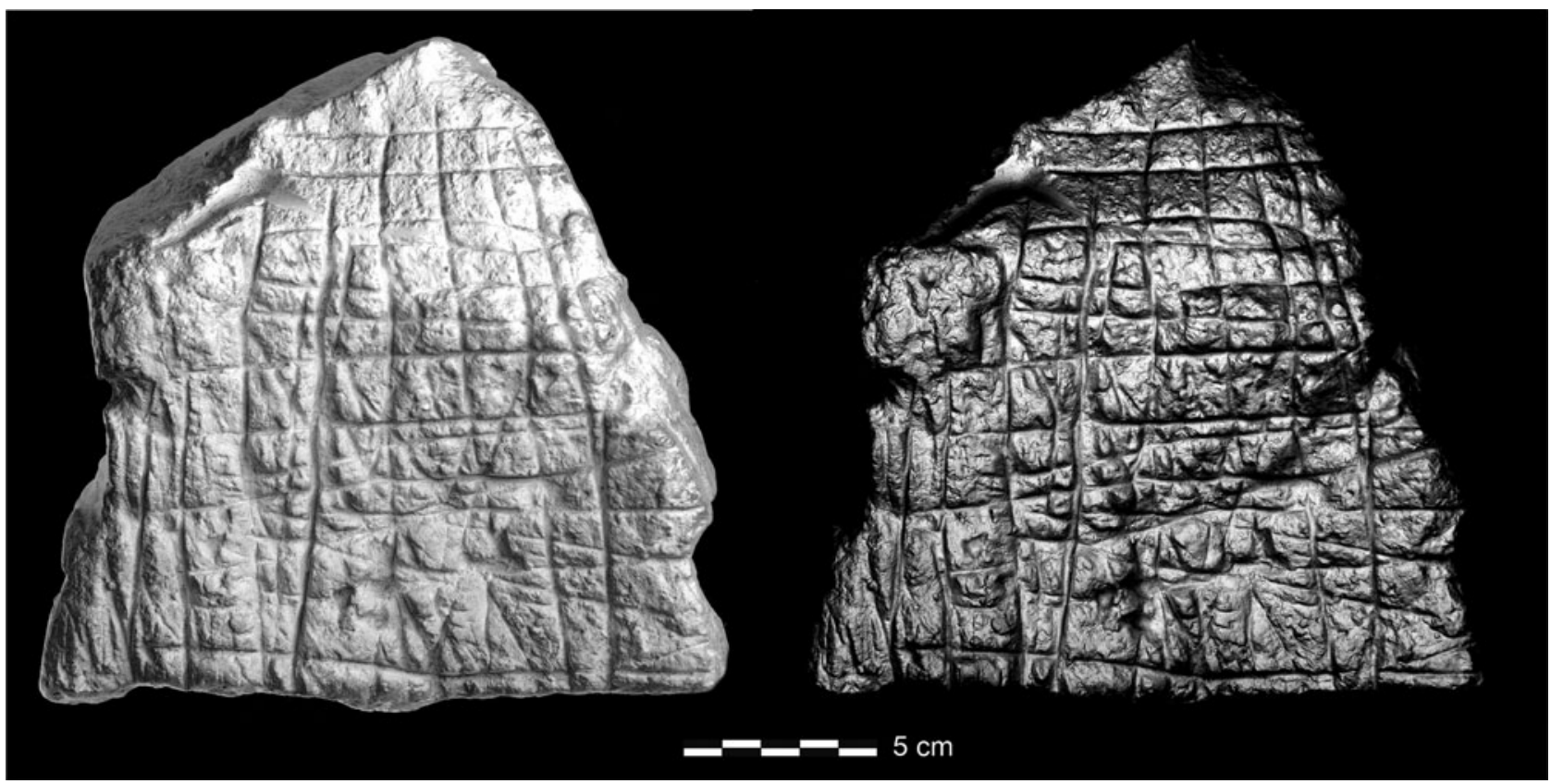

Figure 2. RTI images of the chequerboard incised chalk plaque from the third ditch of the Whitehawk enclosure (Brighton, Sussex). (Image: Marta Díaz-Guardamino. Courtesy of Royal Pavilion \& Museums, Brighton \& Hove.)

The mark-making traditions of Neolithic Britain and Ireland: a chronological overview

The Making a Mark project focused on three key regions of Britain and Ireland (Fig. 1), although a few key artefacts from other regions were also analysed. These regions include: southern England and East Anglia; the Irish Sea region (Wales, eastern Ireland and the Isle of Man); and northeast Scotland (including Orkney). We begin this paper by providing a chronological overview of the development of mark-making traditions in the British and Irish Neolithic (see also Jones \& Díaz-Guardamino 2019, 197-208).

Earlier Neolithic mark making in southern England

The earliest evidence for mark making, around 4050 cal. BC, comes from flint mines, such as Harrow Hill and Cissbury, Sussex, southern England (see Whittle et al. 2011, 257). The Bayesian analysis of radiocarbon dates from Harrow Hill by Frances Healy and colleagues (2011) indicates that flint was worked at Harrow Hill between 4250 and 3705 cal. BC (95 per cent probability), probably 4020-3785 cal. BC (68 per cent probability), and working at the mine ceased 3750-3395 cal. BC (95 per cent probability), probably $3695-3580$ cal. ВС (68 per cent probability). Intercutting linear and curvilinear marks are found on the walls of flint mines, such as shaft 21, Harrow Hill. Digital analysis indicates at least two phases of marking on the panel from Harrow Hill. These marks are typically at important juncture points in mine galleries or to mark rich seams of flint (Teather 2011).

From the thirty-seventh to thirty-fifth centuries cal. BC we also find intercutting linear marks on chalk plaques in the causewayed enclosures of southern and central England. A good example of this is the chalk plaque from Whitehawk (Fig. 2). The four circuits of the Whitehawk enclosure, Brighton, Sussex, begin life between the mid thirtyseventh century and the end of the thirty-sixth cal. BC, with a 95 per cent probability of primary use for 75-260 years (Whittle et al. 2011, 226). Dating from the later activity at the site is the chequerboard' incised chalk plaque from the third ditch which dates to 3660-3560 cal. BC (95 per cent probability), probably 3650-3600 cal. BC (68 per cent probability) (Whittle et al. 2011, 225). The decorated artefacts associated with causewayed enclosures are probably produced as the monuments are being constructed and are discarded (sometimes formally) in the backfill deposits at these sites. Good examples of this are the chalk artefacts, such as chalk balls and phalli, associated with the secondary deposits of the enclosure at Windmill Hill, Wiltshire (Smith 1965; Whittle et al. 2011, 81-96), which date to 3365-3295 cal. BC (94 per cent probability), probably in 3355-3325 cal. BC (68 per cent probability). 


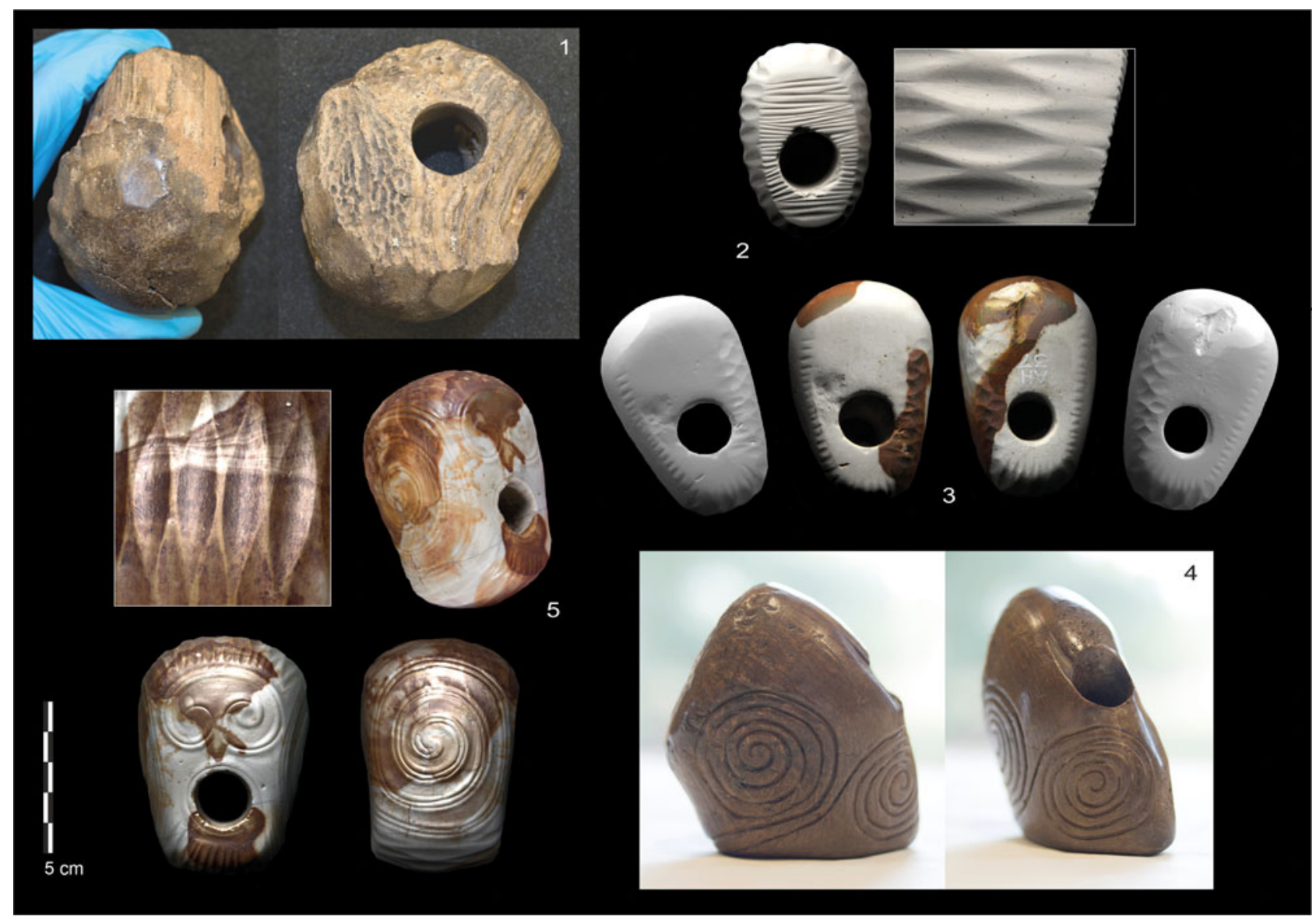

Figure 3. Antler and flint mace heads mentioned in the text. (1) Antler macehead from the Thames, Windmill Lane, Brentford (O1154D): to the left, detail of the faceted decoration and to the right, detail of the furrowed surface; (2) Airdens mace head: RTI images showing details of the ridge- and lozenge-shaped decoration patterns; (3) Urghuart mace head: at the centre, regular photographs showing the colored texture of the surface and, at the sides, the RTI images of both faces, showing details of the ridge- and lozenge-shaped decoration patterns at the edges; (4) Garboldisham macehead, photographs of the mace head from different angles showing the spiral decoration; (5) Knowth mace head: at the top right, normal photograph; at the bottom, RTI images revealing the low-relief decoration (including spirals); at the top left, detail of the lozenge-shaped decoration of the top and bottom of the mace head. (Photographs and RTIs: Marta

Diaz-Guardamino, by permission, respectively, of the Thomas Layton Trust/Museum of London, (C) National Museums Scotland, (C) National Museums Scotland, (c) Moyse's Hall Museum, (C) National Museum of Ireland.)

Middle Neolithic mark making across Britain

After the thirty-fifth century and down to the twenty-ninth cal. $\mathrm{BC}$, we observe a florescence of mark-making activities, not only in southern England but in eastern Ireland, northern Scotland, Wales, East Anglia and Orkney. This is manifested in a series of different phenomena including the decorated antler mace heads deposited in the Thames, consistently dating to between 3500 and 2900 cal. BC (see Loveday et al. 2007, 389), the antler mace head from Garboldisham, Norfolk, decorated with three spiral designs, dating to 3240-3104 cal. BC (56.4 per cent probability)
(Jones et al. 2017) (Fig. 3), the decorated chalk block from Monkton Up Wimborne, Dorset, dating to 3500-3100 cal. BC (Green 2007, 118), and the decorated stone plaque from the stone axe quarry at site B, Graig Lwyd, north Wales (Williams \& Davidson 1998) (Fig. 4), which can be stratigraphically associated with a cache of fresh stone flakes relating to axe making dating to 3110-2910 cal. вС (Williams \& Kenney 2011, 16). In several of these cases we observe evidence for the repetitive reworking of artefacts, or for the making and rapid disposal of decorated artefacts (Jones \& Díaz-Guardamino 2019, 167-83). 


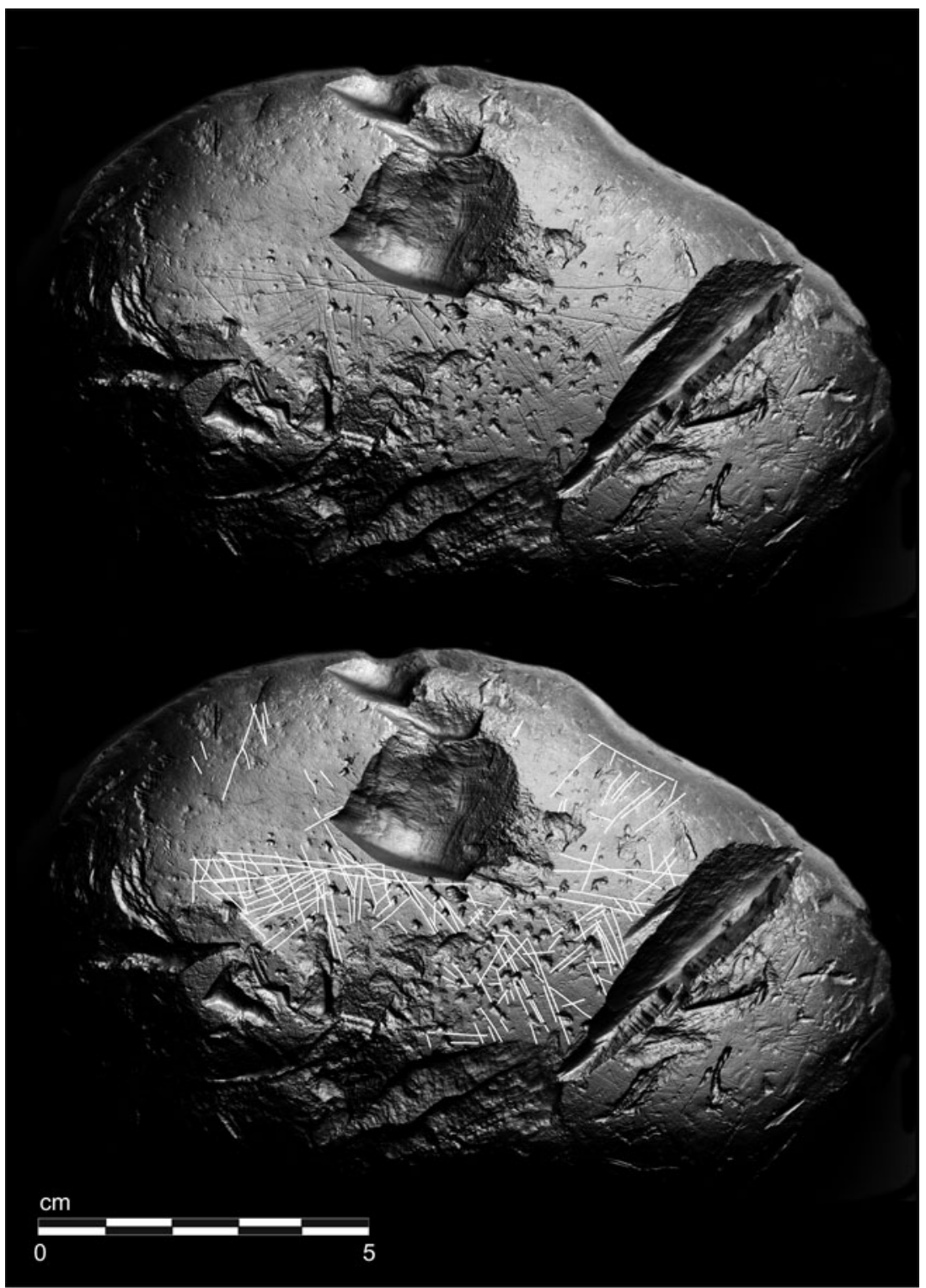

Figure 4. Graig Lwyd plaque, RTI and annotation. (Images: Marta

Díaz-Guardamino. (C) National Museum of Wales.)

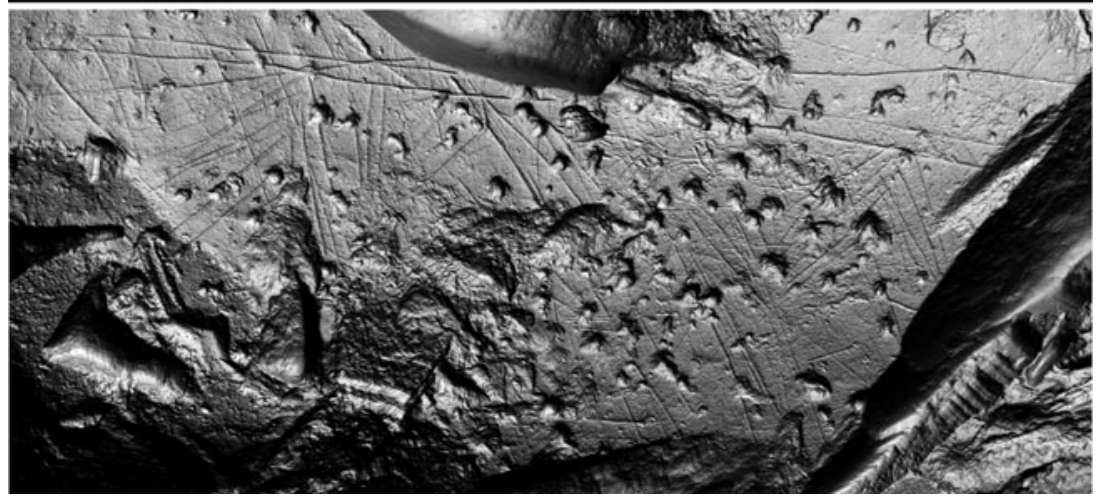

Mark making in Irish passage tombs and Orcadian settlements

These artefacts emerge as local responses to an emergent mark-making tradition. One of the most striking examples of this tradition is the carved passage tombs of eastern Ireland, particularly those in the cemeteries of the Boyne valley and Loughcrew, Co. Meath. Bayliss and O'Sullivan (2013, 55-62) assessed 


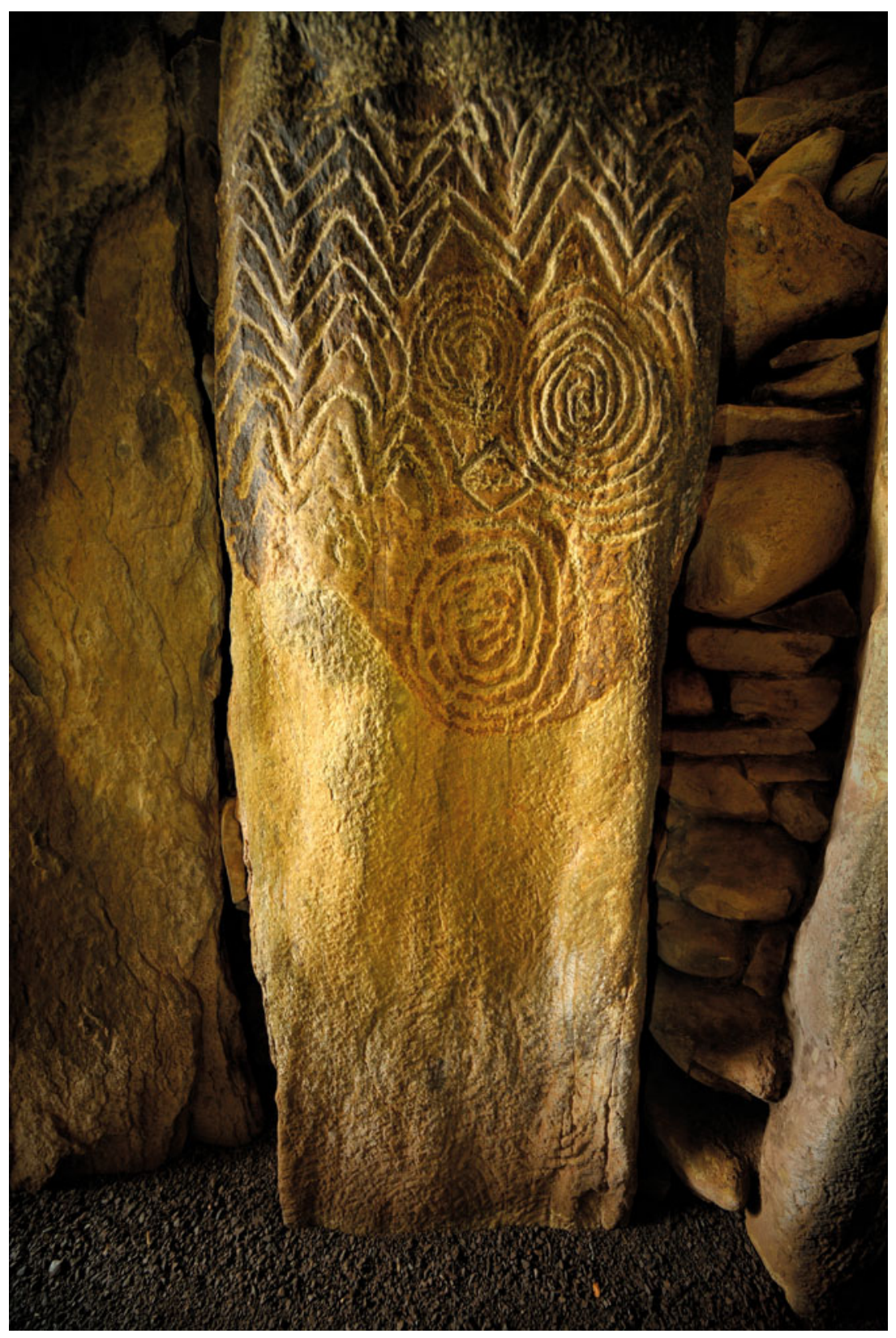

Figure 5. Reworked passage tomb art, Newgrange. (Image (C) Ken Williams.)

the dates from a series of passage tombs across Ireland and produced dates for first construction of 5240-3100 cal. BC (95 per cent probability), probably 3910-3120 cal. BC (68 per cent probability), with an end date for primary use of 3090-2905 cal. BC (95 per cent probability), probably in 3025-2935 cal. BC (51 per cent probability). More precise dates for the use of passage tomb 1, Knowth, indicate the use of the tomb beginning from 3275-3110 cal. BC and ending 2875-2840 cal. BC (95 per cent probability) (Schulting et al. 2017, 370). Analysis by Guillaume Robin (2010) of the tombs of Knowth and
Newgrange (Fig. 5), in the Boyne valley complex, demonstrates the close association between the production of passage-tomb art and the sequential construction of Irish passage tombs. The initial construction of passage tombs begins with the interior chamber. This is followed by a succession of extensions to the passage that enters the chamber. During construction, intensive mark making occurs at the junction points of the passages. This intensive working continues throughout the use of these monuments, and we can detect up to five phases of cumulative carving and re-carving in the interior 
Figure 6. The Truro round slate plaque (Cornwall), RTI snapshots. (Images: Marta Díaz-Guardamino. (c) Duchy of Cornwall, Cornwall Archaeological Unit.)

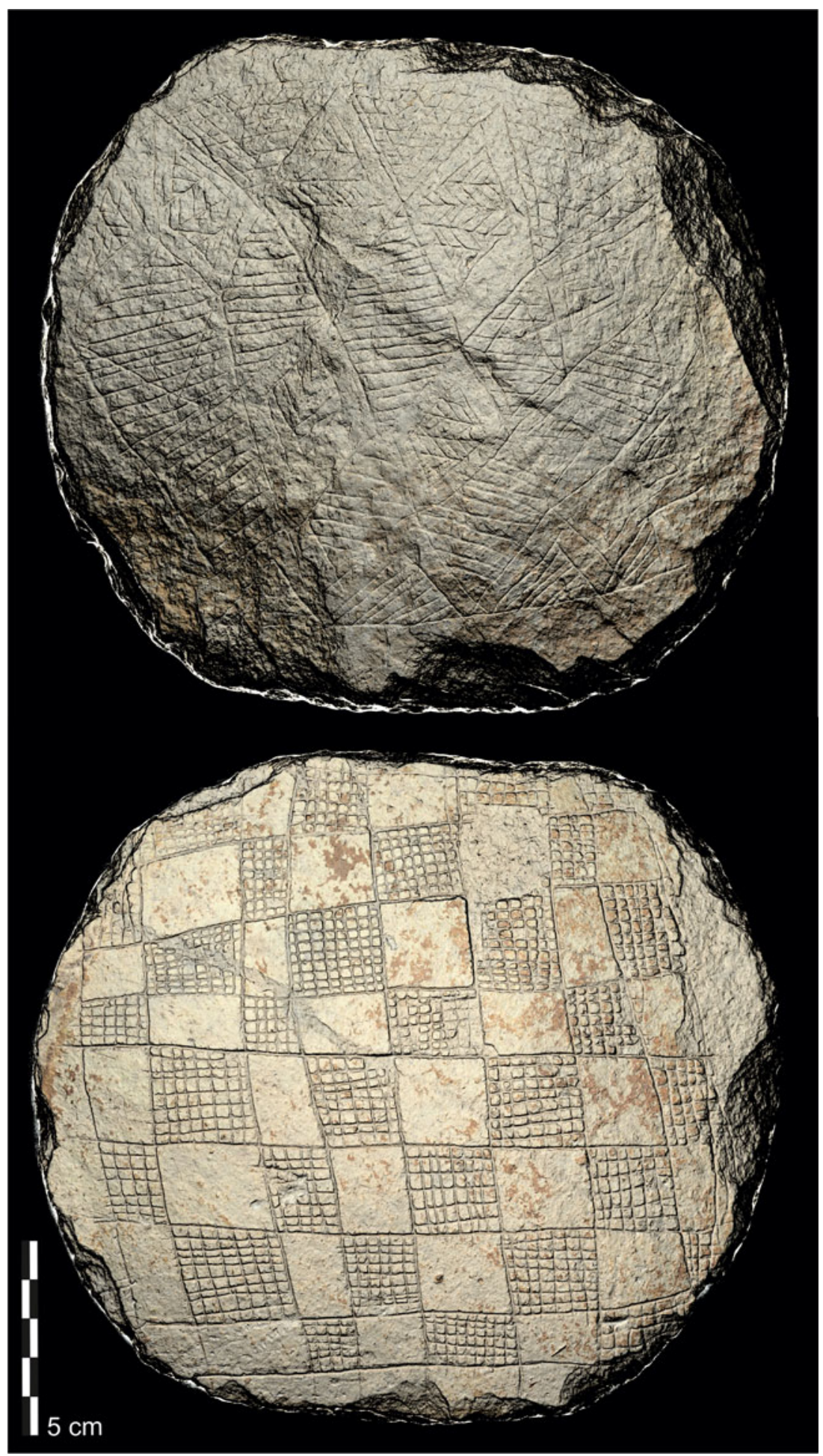

of the monuments, beginning with linear and geometric marks and culminating in three-dimensional sculptural designs (Cochrane 2009; Jones 2004).

A similar set of mark-making practices also occurs in the passage tombs and settlements of
Orkney. Here, Antonia Thomas (2016; 2019) has identified a series of episodes of marking at the passage tomb of Maes Howe and at the settlement sites of Skara Brae and Ness of Brodgar. At the recently excavated site of the Ness of Brodgar it is possible 
Andrew Meirion Jones \& Marta Díaz-Guardamino

to determine that episodes of marking occured during the building and rebuilding of these communal settlement structures.

\section{Mark making and rock art in Britain and Ireland}

Open-air rock art, found in landscapes in northern England, Scotland and western Ireland, is also sometimes marked with images like those found on Irish passage tombs, as well as being marked with distinctive cup-and-ring designs. Rock-art sites appear to be carved over extensive periods of time, and at these sites designs tend to interlock and extend across the rock surface rather than being erased or reworked, although Joana Valdez-Tullett (2019) has identified evidence of recarving and superimposition at a few sites, such as Barmishaw rock (Rombalds Moor, Yorkshire), Backstone Beck 5 (Ilkley Moor, Yorkshire), Dereeny and the main rock at Derrynablaha (Iveragh peninsula, Co. Kerry, Ireland) and Broughton Mains and Drumtroddan 1 (Galloway, Scotland). Rock art is notoriously difficult to date, though dates of 2920-2860 cal. BC were obtained for primary activity associated with rock-art making at Torbhlaren, Kilmartin, Argyll, Scotland (Jones et al. 2011, 115), while pitchstone artefacts which firmly date to the Neolithic (Ballin 2009) have been discovered at rock-art sites in Ben Lawers, Strathtay (Bradley et al. 2012).

\section{The emergence of design and pattern in Later Neolithic Britain}

From the thirty-second to thirtieth centuries cal. BC a new kind of pottery emerged in the northern Isles of Orkney: Grooved Ware. For the first time, pottery was decorated with designs, such as spirals, that had previously been reserved for other materials. Grooved Ware is typically decorated with organized design patterns, some of which relate to basketry. After the twenty-ninth century cal. $\mathrm{BC}$, artefacts are also decorated with more organized kinds of designs; these artefacts are typically associated with Grooved Ware pottery. Good examples of this include the round slate plaque from Woodcock Corner, Truro, Cornwall (Fig. 6), associated with Grooved Ware pottery and with dates of 2880-2570 cal. BC and 29002630 cal. BC (Taylor 2019, 95). One side of this plaque is incised with a chequerboard design, while the opposite face is lightly incised with infilled lozenge and triangle designs (Jones \& Díaz-Guardamino 2019, 60-61). Similarly, the slate plaques from Ronaldsway and Ballavarry, Isle of Man, are decorated with lozenge designs and a series of registers of zig-zag motifs; analysis of these designs using digital imaging techniques indicates that they are repeatedly incised and erased from the plaques (Jones et al. 2016). Recent dates for these artefacts suggest that they date to between the thirty-first and twenty-fourth centuries cal. BC (Crellin 2014, 215). The two chalk plaques from Amesbury, Wiltshire, are also incised with lozenge designs and a complex infilled rectangular design (Harding 1988): dating these artefacts is difficult, but on the basis of similar plaques from Durrington Walls, Wiltshire, they are likely to date from 2525-2470 cal. BC (Parker-Pearson 2012, 110). Probably the most complex designs relate to those on the Folkton Drums, Yorkshire (Fig. 7). These are three chalk cylinders, each of which is intensely decorated with complex infilled triangular and lozenge designs; these artefacts are also extensively revised and erased (Jones et al. 2015). These artefacts, associated with a child burial, also hint at ambiguous representational imagery as each drum is decorated with 'eyebrow' motifs that resemble the human face. The Folkton Drums remain undated, but a single date of 28142678 cal. BC was derived from a similar artefact from Lavant, Sussex (Jones \& Díaz-Guardamino 2019, 75).

\section{Figuration in Later Neolithic Britain}

Alongside the emergence of more organized designs we also observe the appearance of figuration. There are several human figurines of stone from the settlement at the Links of Noltland, Westray, Orkney. On the basis of a recent Bayesian modelling programme (Marshall et al. 2016), the occupation of the Links of Noltland site began 3160-2870 cal BC (95 per cent probability) and took place for $55-350$ years (95 per cent probability); the occupation ended 2850-2640 cal BC ( 95 per cent probability). The best known of the figurines from the Links of Noltland (the so-called 'Orkney Venus') has similar eyebrow motifs to those of the Folkton Drums, as well as distinct dots for eyes. The obverse of this same figurine is decorated with a series of rectangular designs that may resemble clothing; it is evident that this figurine has been revised on several occasions, as have the other figurines from the same site (Jones \& DíazGuardamino 2019, 137-8). Another striking human figurine, this time carved in ash wood (Fig. 8), was deposited below the Bell B trackway within a cluster of pegs that were part of Bell A Track in the Somerset Levels (Coles 1968; Coles \& Coles 1986); radiocarbon dates from a Bell B track ash traverse (Gak-1600, $4840 \pm 100$ вр) and pegs of the Bell A track (BM-382, $4266 \pm 131 \mathrm{bP}$, and BM-383, 4021 \pm 103 вр) (Coles \& Dobson 1989) indicate that the figurine could have been deposited between 3337 and 2287 cal. BC (95 per cent). 


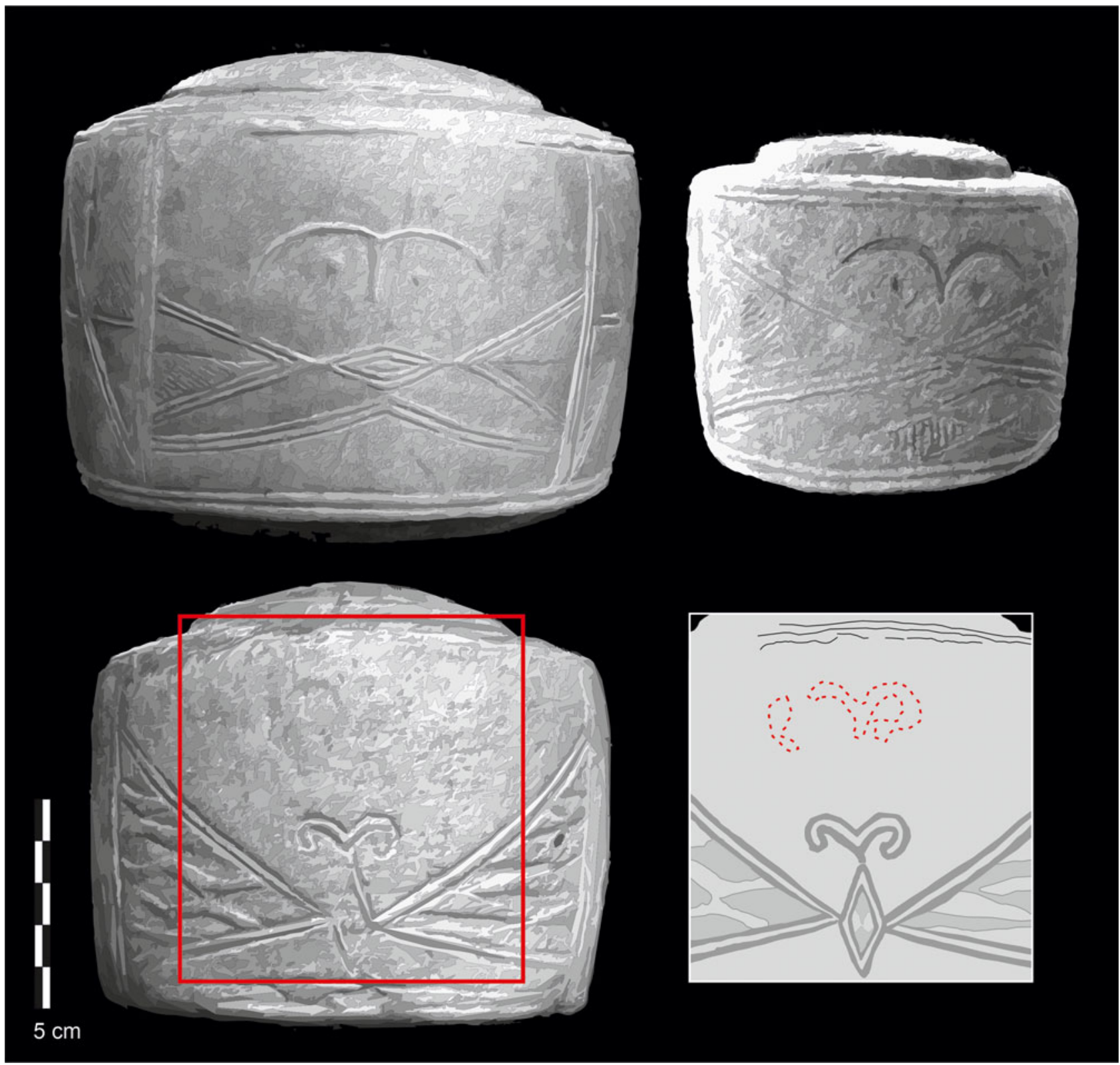

Figure 7. Folkton Drums, Yorkshire, and detail of erased eyebrows on Drum 2, RTI and annotation. (Images: Marta Díaz-Guardamino and Eleni Koutoula. (C) Trustees of the British Museum.)

In addition to the appearance of human figurines, chalk phalli and chalk balls continued to be made and deposited during the Late Neolithic. Some of the most spectacular of these artefacts are derived from henge sites in Dorset, such as Wyke Down, Maumbury Rings and Mount Pleasant. At Maumbury the largest chalk phallus, measuring some $222.6 \mathrm{~mm}$, was deposited midway up an infilled chalk shaft (shaft 10), in close association with a red deer skull; this was one of several shafts dug around the perimeter of the enclosure (Fig. 9)
(Bradley 1975). At Mount Pleasant a collection of chalk artefacts, including chalk balls and up to five chalk phalli are deposited in the enclosure ditch, palisade trench and the ditch of the smaller, site IV enclosure in the middle of the monument (Wainwright 1979). These artefacts, particularly those associated with site IV and the palisade, are closely associated with the basal deposits. It seems likely that the artefacts from Mount Pleasant and Maumbury are derived from local chalk and were fashioned when the monuments were constructed; 


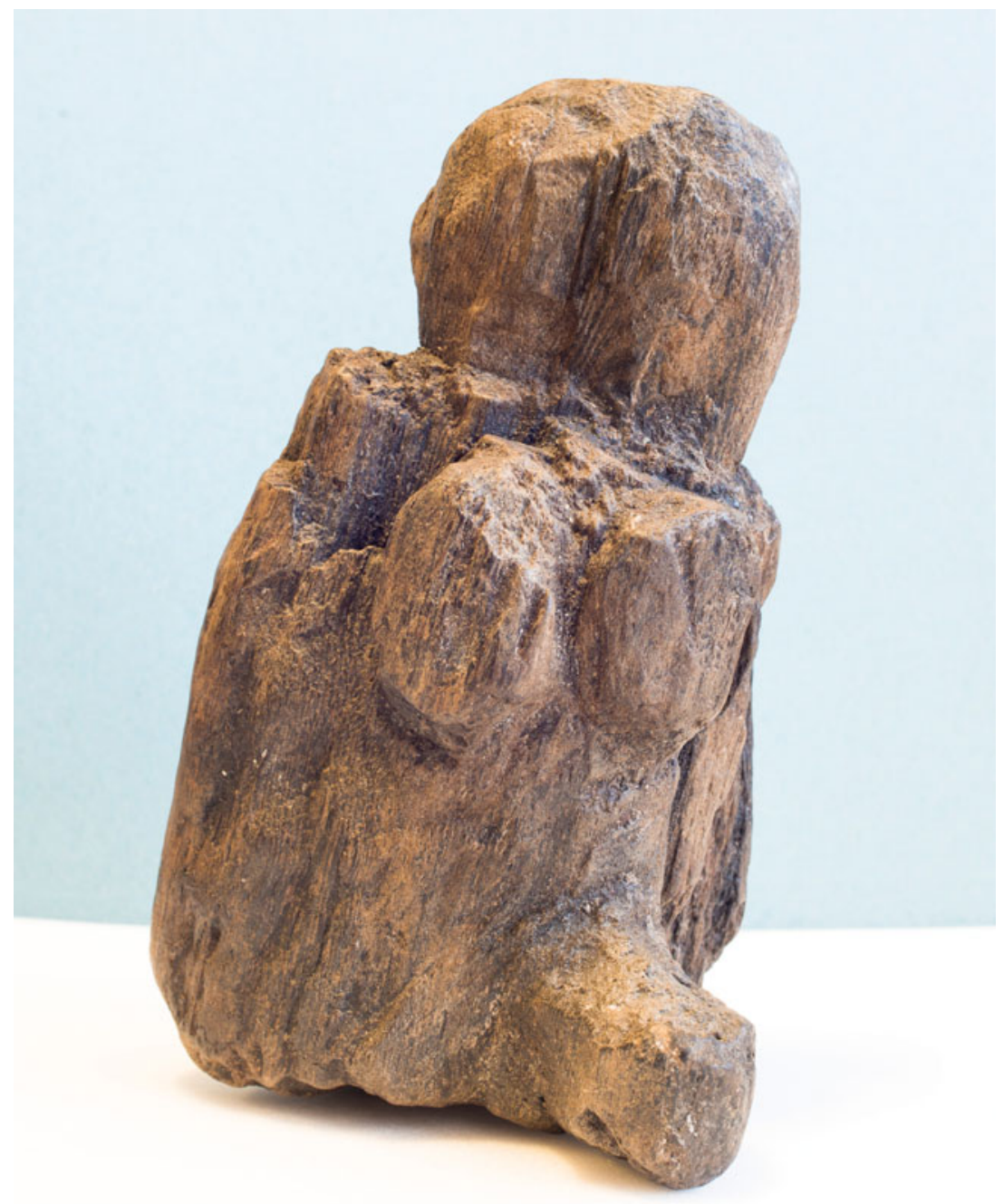

Figure 8. Somerset levels 'God dolly'. (Image: Marta Díaz-Guardamino. Reproduced with thanks to the University of Cambridge Museum of Archaeology \& Anthropology. Accession no. 1968.6.)

indeed, the large scale of the Maumbury phallus is probably due to its manufacture from the large chalk blocks encountered when the $10 \mathrm{~m}$ deep chalk shafts were dug into the lower chalk stratigraphy.

\section{Skeuomorphs in Neolithic Britain and Ireland}

We have mainly discussed the material basis of Neolithic mark making. We now turn to another related form of material practice: the production of skeuomorphs. While at first sight skeuomorphs may seem to set up a relationship of referentiality between prototype and copy, the relationship established during the Neolithic appears to be relational and is based on common, shared properties among materials (see Conneller 2013 for a similar argument). For example, from $c$. the thirty-fourth to twentyninth centuries cal. BC we find a class of carved flint mace heads from Scotland, Wales and Ireland whose form and colour resembles that of a series of similar carved mace heads in antler from the Thames valley in southern England (Fig. 3) (Jones \& Díaz Guardamino 2019, 123-30).

Skeuomorphism appears to be especially significant in the Irish Neolithic and there are many marked and carved artefacts produced of different substances and scales in this region (Jones \& Díaz-Guardamino 2019, 83-102). Bone pins are an important feature of cremation deposits in passagetomb contexts; these pins are often decorated with a series of grooves running at regular, spaced intervals around their circumference. These pins are typically made from sheep or cattle metacarpals or metapodials and as such have a natural medullary channel running longitudinally along the pin. Interestingly, pins of deer antler, such as the example from Fourknocks I passage tomb (Hartnett 1957), are 


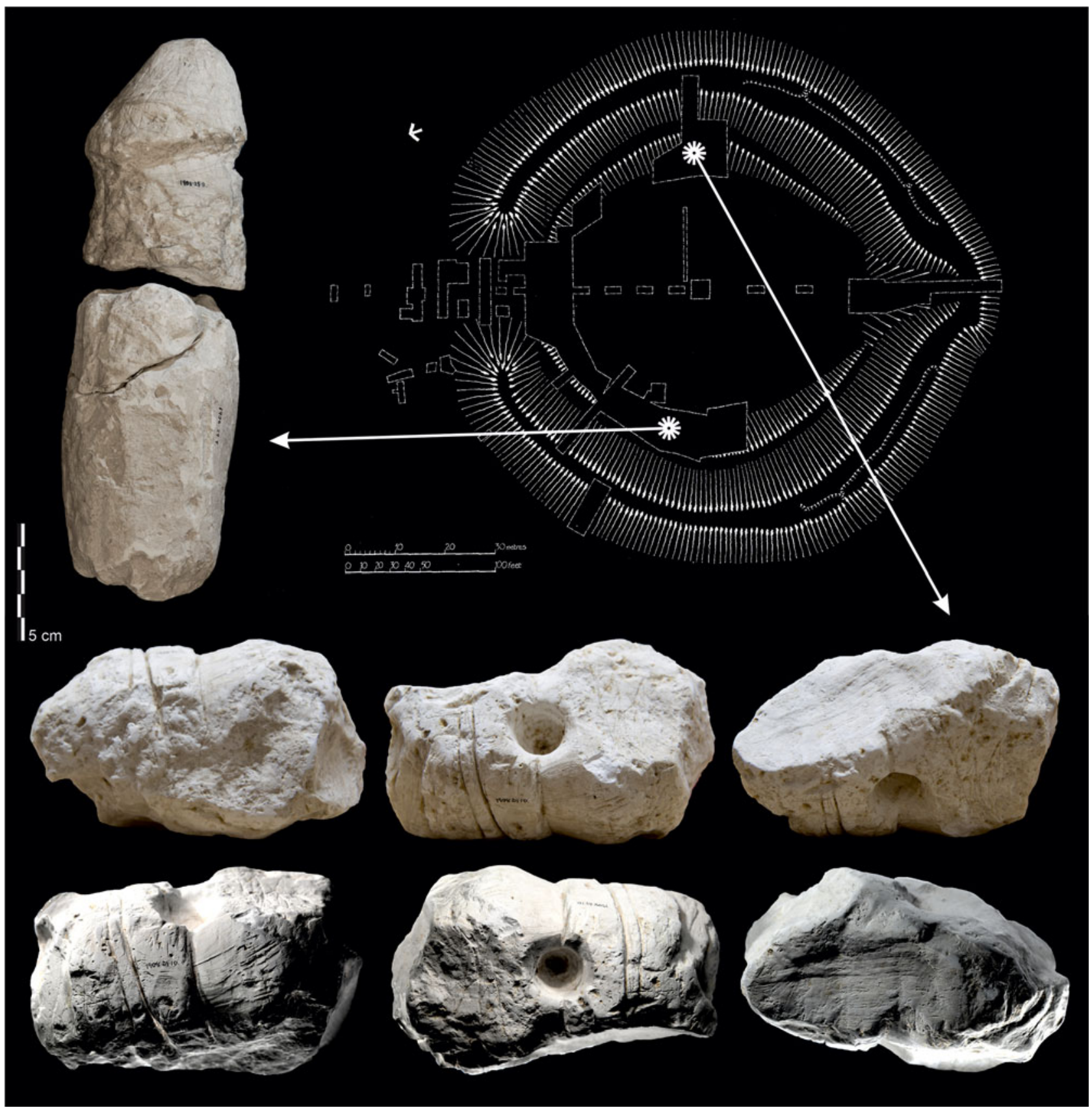

Figure 9. Chalk phallus and worked chalk from Maumbury, and site plan of Maumbury. The phallus was deposited mid-way up shaft 10, while the carved object was found at the base of shaft 14. (Artefact images: Marta Diaz-Guardamino. Site plan: Richard Bradley (1975). Courtesy of Dorset County Museum.)

decorated in the same fashion and also have a carved groove running the length of their shafts; these antler pins are then skeuomorphs of bone pins. The same features can be observed on the large sandstone object deposited at the entrance to the western tomb, Knowth 1 (Cleary et al. 2017, 444-6). This object is also decorated with a series of grooves around its circumference, while the reverse of the object has a channel carved running along its length; a replication of the medullary cavity of bone pins. Although this object is several magnitudes greater in size than bone pins, it is nevertheless also a skeuomorph. Other skeuomorphs include the clay beads from Knowth fashioned to resemble in miniature the form of type $4 \mathrm{~b}$ Scottish carved stone balls (Cleary et al. 2017, 421; Jones 2012, 45-8; Sheridan 
Andrew Meirion Jones \& Marta Díaz-Guardamino

2014) and miniature pestle mace heads of stone and clay (see Jones 2012, 45-8) that resemble their larger counterparts.

The significance of skeuomorphs and design during the Neolithic of Britain and Ireland

The relational practice of skeuomorph making is important, as skeuomorphs are a species of generative material images that grow, transform and metamorphose as fresh iterations are made. This relational mode of making emerges from the thirty-fourth century cal. BC onward, but comes to the fore by the Late Neolithic, after the twenty-ninth century cal. $\mathrm{BC}$, when a new form of image emerges: the human figurine. At this moment we observe the intra-action of two differing ways of relating to materials: the production of relational skeuomorphic forms and the marking of materials. Some figurines, such as the example in ash wood from the Somerset levels trackways (Fig. 8), remained unmarked and were discarded rapidly after production. Other figurines receive intensive marks, such as the example from Links of Noltland, Westray, Orkney. In addition to the body of this figurine being repeatedly marked, we also observe marks that may represent a face.

As noted above, and particularly associated with Grooved Ware related contexts, we also observe the production of organized designs on marked artefacts, such as the alternating chequerboard designs on the Truro plaque (Fig. 6), the lozenge and zig-zag motifs on the plaques from the Isle of Man, the lozenge and rectangular motifs on the Amesbury chalk plaques and the complex lozenge and triangle motifs on the Folkton Drums (Fig. 7). These have a close resemblance to the kind of systematic patterns produced by basketry and weaving (see e.g https://penelope.hypotheses.org/). It is difficult to establish plausibly a link between these Late Neolithic carved motifs and woven patterns, as the evidence for weaving is sparse during this period in Britain and Ireland. More cautiously, we are perhaps better recognizing that the organized designs of the Late Neolithic are related to basketry or other craft activities. The relationships between Grooved Ware pottery and basket designs have long been noted (Cleal \& MacSween 1999; see also Hurcombe 2008), while there are preserved examples of Irish Neolithic woven baskets from Twyford, Co. Westmeath (Raftery 1970), and Carrigdirty, Co. Limerick; this last example being dated to 38003400 cal. BC (O'Sullivan 1997). In rare cases we can see quite direct relationships between woven baskets and Grooved Ware pottery, such as the small Grooved Ware vessel (SF 1890) from house 3,
Barnhouse, with a distinct basket impression on its base (Downes \& Richards 2005, 70). Less directly, Teather and Kenney $(2016,6)$ suggest that the Folkton Drums may be skeuomorphic forms of lidded wooden or ceramic containers. We might then regard the relationships established between different materials and substances through the making of organized designs or patterns as a component of a well-established practice of skeuomorphism.

Our account has covered two millennia of markmaking practices, and from this we have learnt a series of things. Firstly, mark making intersects with other activities: with the mining of flint and the quarrying of stone, with the construction of monuments, with burials. Secondly, mark making begins as a localized practice in the south of England, but by the thirty-fifth century cal. $\mathrm{BC}$ we see an emerging network of regions become connected by shared designs and mark-making practices (these areas include eastern Ireland, northern Scotland, Wales, southern England, East Anglia); at this juncture the design of marks become more visually complex. From the thirty-second to thirty-first centuries in Orkney, and from the twenty-ninth century in the rest of Britain and Ireland, we note that mark making on artefacts becomes more organized, with distinctive patterned designs appearing; these emerge alongside a new interest in figuration with the appearance for the first time of human figurines.

Most significant, we have found that marks are ephemeral, and there are numerous examples of erasure, overcutting and reworking. In many cases, marked artefacts are also discarded rapidly. Of particular importance is the relationship between mark making and the materials marked. While there is a close relationship between maker, material and place we also need to remind ourselves that, between the thirty-fifth and twenty-ninth centuries cal. BC, each of these artefacts is a component in a more extensive network of connectivity that emerges across a host of regions. Marked artefacts are at once situated in local and inter-regional networks of relationships (Jones 2017), though they generally remain in the localities in which they were made. Marked artefacts therefore contrast strongly with unmarked artefacts, such as polished stone axes and polished-edge knives, which are instead widely circulated (Jones \& Díaz-Guardamino 2019, 205-6).

\section{Marking events: marking as practice in the British and Irish Neolithic}

There are two important outcomes of the Making a Mark project. First, the use of digital imaging 
Figure 10. (Upper) Monkton Up Wimborne chalk block as seen from various angles. (Image: Marta Diaz-Guardamino. Courtesy of Martin Green); (lower) Monkton Up Wimborne site section. (Image (C) Martin Green/ Richard Bradley.)
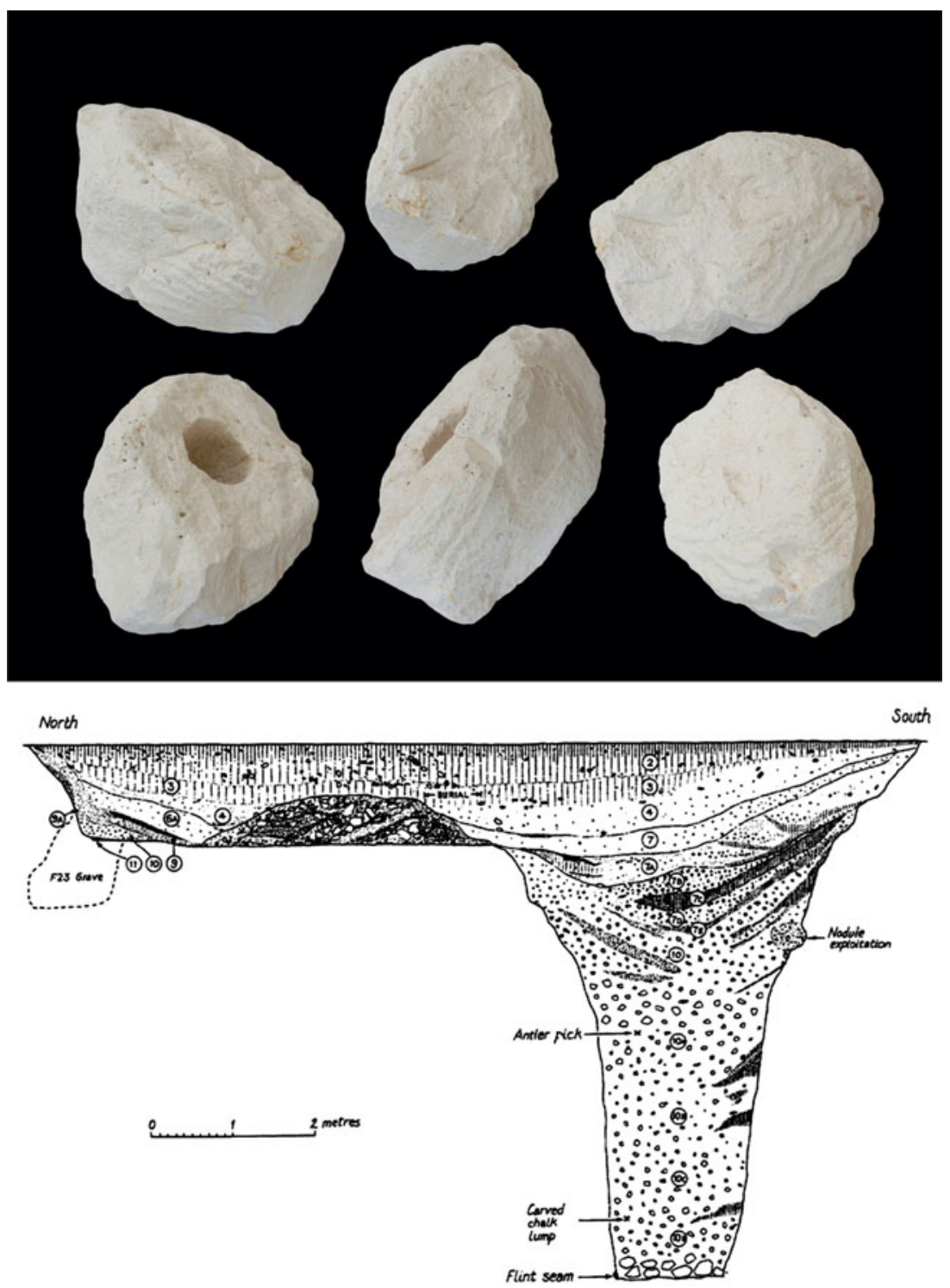

techniques has shown for the first time that Neolithic mark making is a repetitive practice: marks are ephemeral; they are made and remade, or marked artefacts are made and rapidly discarded. Second, our chronological analysis shows that while the practice of remaking continues throughout the Neolithic, we also see significant shifts in practice, particularly from the thirty-fifth to twenty-ninth centuries cal. $\mathrm{BC}$, when we observe an expansion in decorated artefacts, and after the twenty-ninth century when we begin to see more organized patterned designs on artefacts.

Neolithic mark making emphasizes the importance of presence; the relationship between mark makers and the materials-to-be-marked seems to be of particular importance. It is also critically important that marks are manifested in specific places (such as the marking of specific places in the landscape, as with rock art), and at particular moments in time. We can see this clearly in a series of practices. The marks that we observe on flint mines are a clear example where the event of flint extraction is marked; this practice persists from the earliest Neolithic at sites like Harrow Hill, Sussex, to the later Neolithic at sites like Grimes Graves, Norfolk. It was also evident at Monkton Up Wimborne, Dorset (Fig. 10), where a large chalk block, evidently derived from lower chalk geology, was extracted, carved and redeposited back into a shaft that may have been dug for flint extraction. Likewise, the 
Graig Lwyd (Penmaenmawr, north Wales) plaque (Fig. 4) is a testament to the marking of events associated with quarrying stone for the production of polished stone axes.

From quite early on, marking was also related to the events of monument building. We may detect this in the evidence of worked chalk deposited in the ditches of long barrows such as Thickthorn Down, Dorset (Drew \& Piggott 1936), but we observe this particularly clearly with the large quantities of worked chalk associated with causewayed enclosures such as Whitehawk and the Trundle, Sussex (Curwen 1929), and Windmill Hill, Wiltshire. We would argue that chalk artefacts were probably worked during the event of monument building and discarded in the fills of ditches; due to the ephemeral nature of the chalk the artefacts are unlikely to have survived for long without rapid deposition after making. In some cases, the event of ditch digging itself was marked, as with the much later causewayed enclosure at Flagstones, Dorset (Woodward 1988; Woodward \& Smith 1988), where the ditches received marks of several phases. The relationship between marked artefacts and monument building continues into the Later Neolithic, where we observe decorated artefacts being associated with the ditches, post-holes and shafts of henges and henge-like enclosures at Woodhenge, Wiltshire (Cunnington 1929), Wyke Down, Maumbury (Fig. 9), and Mount Pleasant, Dorset. We could also regard the deposition of the wooden Somerset Levels 'god-dolly' figurine beneath the Bell B trackway (Fig. 8) as a worked artefact that marked the event of the trackway construction.

In some cases, mark making marks events that have already happened, and might signify the closure of activities at places. For example, we could argue that the Graig Lwyd plaque marks the final quarrying activities at the site. In a more dramatic fashion, the rock-art site at Copt Howe, Cumbria, is sighted on the major Langdale Pike axe quarry. New radiocarbon dates suggest that the end of axequarrying events took place 3696-3484 cal. BC (95.4 per cent probability) (Edinborough et al. 2020), while recent excavations at Copt Howe suggest that the motifs are likely to have been carved 3300-2900 cal. BC on the basis of comparisons with Irish passage-tomb art (Bradley et al. 2019, 190). If the dates for Copt Howe are accepted, then the rock-art site signifies an important physical and temporal threshold, after the axes, which marks the end of activities at Langdale.

Probably the most compelling argument for mark making being associated with the event of monument building is the evidence of passage-tomb art being related to the differing phases of tomb and passage construction in Irish passage tombs (Robin 2010). Equally compelling is the evidence for mark making being associated with the event of building and rebuilding stone-built settlements in Orkney (Thomas 2016).

Finally, mark making is also associated with the events surrounding burial. This is most clearly observed for the Folkton Drums, Yorkshire, and is also the case for the abundance of decorated artefacts associated with human remains in Irish passage tombs. This may also be true for the deposition of chalk in the ditches of the oval barrow at North Marden, Sussex (Drewett et al. 1986), though here the chalk artefacts are more likely to relate to the event of barrow construction rather than burial.

Marking is event-based, but the potency of marks does not persist in all cases. In many circumstances marked materials must be erased and re-marked to reiterate the eventfulness of the connection between mark maker, material and place or occasion.

\section{Marking change: marking and materials in the British and Irish Neolithic}

Not all decorated artefacts are associated with the events of mining, quarrying, monument construction, and burial. However, at a general level marks appear to manifest an intra-action between mark maker and material and presence the event of their making. Critically, the activity of mark making is also one of differentiation. Marking is an exploratory and experimental process closely entangled with other kinds of activities. Marking on the surface of these artefacts helps to differentiate the material from its environment, marking it out as something different. Although marks are made on portable artefacts, these artefacts do not appear to travel and remain situated in their local region. Marks allow materials to stand apart from the local, although they also evoke marks found in other distant places. In effect the mark helps to fold, assemble, or relate other distant marked materials, and their attendant set of practices, within local materials, enabling an emerging network of relationships to be established (Jones 2017, 92). Marks are a means by which relationships between materials are mapped, affirmed and sometimes re-aligned.

The simple act of marking is an alchemical process. At a stroke, local materials-whether of slate or antler, chalk, or bone-change, transform and become elements in other distant sets of practices. 
However, this process of marking was not a one-off in which sets of relations are fixed for all time. Instead we observe, as with the slate plaques of the Isle of Man, the continual and repetitive act of marking, and erasing, and re-marking (Jones et al. 2016). In this way, the relations established between mark maker and material, and marks and other places, is continually reaffirmed or realigned.

If we consider mark making in communicative terms, then Neolithic marking operates at a series of registers. In many cases mark making is an intimate activity, and the audience for the mark is minimal; possibly simply the mark maker and one or two others, as marked materials are often rapidly discarded or incorporated into monuments and settlements during their building. By contrast, in some cases, as with open-air rock-art sites, marks are more persistent and are added to over considerable periods of time and are therefore probably addressed to a wider audience.

However, careful analysis of the way in which mark making relates to materials suggests that a more nuanced analysis would replace the terms 'communication' and 'audience' with that of 'intra-action', a notion proposed by feminist scholar Karen Barad $(2007,33)$ to refer to the mutual constitution of different agencies, subject and object, through interactions. Materials are not the passive recipients of marks addressed to an audience; the human mark maker is also the audience for the material. Marks on Neolithic artefacts, sites and monuments physically define, and make present, the process of differentiation and transformation undergone by those materials. Rather like the growth rings of trees, marks manifest the unfolding of materials over time; mark making evokes the changes undergone by materials.

The relationship between mark making and skeuomorphs might not be immediately apparent, but we need to remember that, just as marks are a way of establishing connections between materials, so the modelling of one substance with the form of another, a skeuomorph, is another means of drawing attention to the relationships between materials. Both mark making and the production of skeuomorphs are experimental practices concerned with drawing out and mapping potential connections and distinctions between the properties of materials.

\section{Marking, repetition and differentiation}

To consider the experimental quality of mark making and skeuomorph making further we discuss Barad's (2007) concept of mattering, and her associated notion of differentiation.
Karen Barad's work engages with Niels Bohr's account of quantum mechanics to argue for the inseparability of matter and meaning. Barad (2007, 140) proposes that entities (such as materials and humans) do not pre-exist relationships, rather they emerge through specific intra-actions. Whereas the term 'interaction' implies action linking pre-existing entities, 'intra-action' implies action that connects, entangles and co-constitutes entities (see above). Matter is not distinct from human agency and discourse as traditional representational approaches would have it; instead matter is substance in its intra-active becoming. Matter is not a thing, but a doing, it is a congealing of agency (Barad 2007, 151). Central to Barad's analysis is that matter is a dynamic and shifting entanglement of relations, rather than a property of things (Barad 2007, 224). Mattering is a process of differentiation, a way in which the world is dynamically articulated and configured. Crucially, Barad argues that this process of differentiation can be distinguished by the marks that persist on bodies that intra-act (these bodies might be human, animal, or things).

The kinds of practices we have discussed for marked artefacts during the British and Irish Neolithic offer an excellent example of mattering; what our analysis reveals is the marks persisting from the intra-action between humans and materials. These marks evince ways in which Neolithic communities in Britain and Ireland differentiated and configured the relationships between different kinds of materials. These processes of differentiation also have an internal dynamic; differentiation encapsulates change. One of the key findings of the Making a Mark project is the ephemerality of marks and the repetition of mark-making activities. It is precisely this repetition that is the seed for change, since change occurs as actions are continually repeated.

To think about the relationship between repetition and differentiation it is helpful to turn to the work of philosopher Gilles Deleuze, particularly his book Difference and Repetition ([1968] 1994). For Deleuze, repetition is not related to the same thing occurring over and over again; repetition is not related to mimesis. Instead, he argues that repetition is connected to the power of difference. Difference is a productive process that produces variation through each repetition. As such, repetition is considered in terms of discovery and experimentation. Each new repeated action, each intra-action (in Barad's terms), enables new experiences and affects to emerge.

The chronological sequence of mark-making practices we have discussed during the British and Irish Neolithic offers superb examples of repetitive 
mark making and how this gradually over time leads to differentiation as mark-making traditions expand geographically from the thirty-fourth to the twentyninth centuries cal. $\mathrm{BC}$, and then become more complex and ordered after the thirty-first century cal. BC for Orkney, and after the twenty-ninth century cal. BC elsewhere. Mark making leads to the discovery of new ways of relating form, through skeuomorphs, eventually enabling other craft activities, such as basketry, to be modelled in novel materials, such as pottery and chalk. Ultimately, this experimental encounter between materials of differing forms leads to the production of recognizable human figurines. Mark making is an ongoing process which does not end once marks are produced. Rather, marks are the impulse for further mark making in an on-going process of differentiation and unfolding. Neolithic marks are not one- or two-dimensional entities; instead they are four-dimensional events or processes involved in the mapping of relations yet to come.

\section{Conclusion}

Our arguments concerning the importance of repetitive practices of mark making and their role in the gradual differentiation of decorated artefacts over the course of the British and Irish Neolithic resonate strongly with Gosden and Malafouris' (2015) recent call for more attention to be paid to an archaeology of process. They remark $(2015,710)$ that important long-term histories derive from the interaction between the flows of substances making up living things, and of materials'. It is precisely the long-term histories resulting from intra-actions between human mark makers and materials that we have mapped throughout this paper. We want to conclude by considering how these mark-making traditions intrarelate with other activities during the Neolithic of Britain and Ireland.

One of the key findings of our work has been the importance of process, of a sense of on-going change and incompleteness in Neolithic mark-making traditions. This is interesting, as archaeologists have noted a similar sense of change and incompletion in the monument traditions of the British and Irish Neolithic. For example, Lesley McFadyen (2007) has drawn our attention to the ad hoc building and persistent reworking and revision of the long barrows of the Costwold-Severn tradition. In the same sense, causewayed enclosures have long been discussed as incomplete projects (Bradley 1993; Evans 1988). For the Later Neolithic, Jim Leary and David Field (2010) discuss the emergent processes involved in the construction of Silbury Hill, Wiltshire, while Mark Gillings and Josh Pollard (2016) have likewise drawn our attention to the movement of stones and processes of making involved in forming the henge at Avebury and other locations in the Avebury landscape. Finally, we have known for some time that the building of one of the most famous Neolithic monuments-Stonehenge, Wiltshire-was an unfinished project spanning over 1500 years (Bradley 1993), a point confirmed by a new radiocarbon-dating programme (Parker-Pearson et al. 2007).

We might also regard experimentation to be key to Neolithic crop production, if we accept Stevens and Fuller's (2012) argument for the abandonment of agriculture in the Late Neolithic. More nuanced analyses backed by Bayesian chronologies for Neolithic Ireland (Whitehouse et al. 2014) indicate marked shifts towards agriculture c. $3750 \mathrm{cal}$. BC and dips in activity from 3400 to 3100 cal. BC, while for other regions such as Scotland, Bishop (2015) calls into question the abandonment of agriculture during the Later Neolithic. However we read the evidence, a complex picture of regional shifts and changes seems to emerge.

Experimentation and transformative processes lie, too, at the heart of food production and processing. The emergence of ceramics at the beginning of the Neolithic allowed for a greater degree of complexity in the processing of foods and the production of new foods, such as bread. As Emilie Sibbesson has recently argued (2019), it also offers the potential for new kinds of preservation processes, such as fermentation; transformation and process lie at the heart, then, of the most fundamental Neolithic practices.

A recognition of the importance of process in the British and Irish Neolithic has been slow in coming (see also Gosden \& Malafouris 2015 for a similar point more generally). It is precisely the fact that process has been overlooked for so long that has made the mark-making traditions of Neolithic Britain and Ireland so difficult for archaeologists to comprehend. Archaeologists, enculturated in the post-Renaissance world of representations, have repeatedly attempted to render the processes of mark making in terms of static representations. As we have shown here, the recognition of process in fact illuminates our understanding of British and Irish Neolithic mark making.

\section{Acknowledgements}

We are both grateful to the Leverhulme Trust for the receipt of grant RPG-2014-193 for this research. We would also like to thank Sean Taylor, Cornwall Archaeological Unit, for his help with information on the 
Woodcock Corner site. Andrew Meirion Jones would also like to thank David Wengrow for an invitation to present this research at a conference in Freiburg, Germany; this was an important stimulus for this paper. He would also like to thank Ina Berg, Julian Thomas and Hannah Cobb and the participants of a departmental seminar at Manchester University who also provided comments which helped shape it.

\section{Supplemental online material}

We will provide access to the digital datasets used for the research presented in this paper (i.e. RTI and 3D models).

Andrew Meirion Jones
Department of Archaeology and Classics
Stockholm University
Wallenberglaboratoriet
SE-10691 Stockholm
Sweden
Email: andrew.jones@ark.su.se

Marta Díaz-Guardamino Department of Archaeology

Durham University

Lower Mount Joy

South Road

Durham DH1 3LE

UK

Email: marta.m.diaz-guardamino@durham.ac.uk

\section{References}

Back Danielsson, I.-M. \& A.M. Jones, 2020. Images in the Making. Art, process, archaeology. Manchester: Manchester University Press.

Ballin, T.B., 2009. Archaeological Pitchstone in Northern Britain. Characterization and interpretation of an important prehistoric source. (BAR British series 476.) Oxford: Archaeopress.

Bayliss, A., P. Marshall, C. Richards \& A. Whittle, 2017. Islands of history: the Late Neolithic timescape of Orkney. Antiquity 91, 1171-88.

Bayliss, A. \& M. O'Sullivan, 2013. Interpreting chronologies for the Mound of Hostages, Tara, and its contemporary context in Neolithic and Bronze Age Ireland, in Tara: From the past to the future eds M. O'Sullivan, C. Scarre \& M. Doyle. Bray: Wordwell, 26-104.

Barad, K., 2007. Meeting the Universe Halfway. Quantum physics and the entanglement of matter and meaning. Durham (NC): Duke University Press.

Bishop, R.R., 2015. Did Late Neolithic farming fail or flourish? A Scottish perspective on the evidence for Late Neolithic arable cultivation in the British Isles. World Archaeology 47(5), 834-55.
Bradley, R., 1975. Maumbury Rings, Dorchester: the excavations of 1908-1913. Archaeologia 105, 1-97.

Bradley, R., 1993. The Significance of Monuments. London: Routledge.

Bradley, R., A. Watson \& H. Anderson-Whymark, 2012. Excavations at four prehistoric rock carvings on the Ben Lawer Estate, 2007-2010. Proceedings of the Society of Antiquaries of Scotland 142, 27-62.

Bradley, R., A. Watson \& P. Style, 2019 After the axes? The rock art at Copt Howe, north-west England and the Neolithic sequence at Great Langdale. Proceedings of the Prehistoric Society 85, 177-92.

Cleal, R. \& A. MacSween (eds), 1999. Grooved Ware in Britain and Ireland. Oxford: Oxbow.

Cleary, K, G. Eogan, A. Little, G. Warren, R. Goodhue, F. McCormick \& G. Sevastopulo, 2017. Artefacts from Knowth, in The Passage Tomb Archaeology of the Great Mound at Knowth, eds G. Eogan \& K. Cleary. Dublin: Royal Irish Academy, 411-85.

Cochrane, A., 2009. Additive subtractions: addressing pick dressing in Irish passage tombs, in Archaeology and the Politics of Vision in a Postmodern context, eds J. Thomas \& V. Oliveira Jorge. Cambridge: Cambridge Scholars, 163-85.

Coles, B. \& J. Coles, 1986. Sweet Track to Glastonbury. The Somerset Levels in prehistory. London: Thames \& Hudson.

Coles, J.M., 1968. A Neolithic God-dolly from Somerset, England. Antiquity 42, 275-7.

Coles, J.M. \& M.J. Dobson, 1989. Calibration of radiocarbon dates from the Somerset Levels. Somerset Levels Papers 15, 64-9.

Conneller, C., 2013. Deception and (mis)representation: skeuomorphs, materials and form, in Archaeology after Interpretation: Returning materials to archaeological theory, eds B. Alberti, A.M. Jones \& J. Pollard. Walnut Creek (CA): Left Coast Press, 119-33.

Crellin, R.J., 2014. Changing Times: The Emergence of a Bronze Age on the Isle of Man. Unpublished PhD thesis, University of Newcastle.

Crellin, R.J., 2020. Change and Archaeology. London: Routledge.

Cunnington, M.E., 1929. Woodhenge. A description of the site as revealed by excavations carried out there by Mr. and Mrs. B. H. Cunnington 1926-8. Also of four circles an earthwork enclosure south of Woodhenge. Devizes: Simpson.

Curwen, E.C., 1929. Excavations in The Trundle, Goodwood, 1928. Sussex Archaeological Collections 70, 33-85.

Deleuze, G., [1968] 1994. Difference and Repetition (trans. P. Patton). London: Continuum.

Downes, J. \& C. Richards, 2005. The dwellings at Barnhouse, in C. Richards (ed.) Dwelling among the Monuments. The Neolithic village of Barnhouse, Maeshowe passage grave and surrounding monuments at Stenness, Orkney. Cambridge: McDonald Institute for Archaeological Research, 57-127.

Drew, C.D. \& S. Piggott, 1936. The excavation of long barrow 163a on Thickthorn Down, Dorset. Proceedings of the Prehistoric Society (1936), 77-96. 
Drewett, P., C. Cartwright, S. Browne, et al., 1986. The excavation of a Neolithic oval barrow at North Marden, West Sussex, 1982. Proceedings of the Prehistoric Society 52, 31-51.

Edinborough, K., S. Shennan, A. Teather, et al., 2020. New radiocarbon dates show Early Neolithic date of flintmining and stone quarrying in Britain. Radiocarbon 62 (1), 75-105.

Evans, C., 1988. Acts of enclosure: a consideration of concentrically-organised causewayed enclosures, in The Archaeology of Context in the Neolithic and Bronze Age: Recent trends, eds J.C. Barrett \& I.A. Kinnes. Sheffield: Department of Archaeology and Prehistory, 85-95.

Gillings, M. \& J. Pollard, 2016. Making megaliths: shifting and unstable stones in the Neolithic of the Avebury landscape. Cambridge Archaeological Journal 26(4), 537-59.

Goldhahn, J., 2019. Birds in the Bronze Age: A north European perspective. Cambridge: Cambridge University Press.

Gosden, C. \& L. Malafouris, 2015. Process archaeology (P-arch). World Archaeology 47(5), 701-17.

Green, M., 2007. Monkton-Up-Wimborne Late Neolithic pit circle/shaft complex, in Prehistoric Landscape Development and Human Impact in the Upper Allen Valley, Cranborne Chase, Dorset, eds C. French \& H. Lewis. Cambridge: McDonald Institute for Archaeological Research, 114-22.

Harding, P., 1988. The chalk plaque pit, Amesbury. Proceedings of the Prehistoric Society 54, 320-27.

Hartnett, P.J., 1957. Excavation of a passage grave at Fourknocks, Co. Meath. Proceedings of the Royal Irish Academy 58C, 19-277.

Healy, F., A. Bayliss, A. Whittle, et al., 2011 South Wessex, in Gathering Time: Dating the Early Neolithic Enclosures of Southern Britain and Ireland, eds A. Whittle, F. Healy \& A. Bayliss. Oxford: Oxbow, 111-202.

Hurcombe, L., 2008. Organics from inorganics: using experimental archaeology as a research tool for studying perishable material culture. World Archaeology 40(1), 83-115.

Ingold, T., 2013. Making. Anthropology, archaeology, art and architecture. London: Routledge.

Ingold, T., 2018. Anthropology and/as Education. London: Routledge.

Jones, A. 2004. By way of illustration: art, memory and materiality in the Irish Sea and beyond, in The Neolithic of the Irish Sea: Materiality and traditions of practice, eds V. Cummings \& C. Fowler. Oxford: Oxbow, 202-13.

Jones, A.M. 2012. Prehistoric Materialities. Becoming material in prehistoric Britain and Ireland. Oxford: Oxford University Press.

Jones, A.M., 2015. Meeting pasts halfway: a consideration of the ontology of material evidence in archaeology, in Material Evidence: Learning from archaeological practice, eds A. Wylie \& R. Chapman. London: Routledge, 344-58.
Jones, A.M. 2017. The art of assemblage: styling Neolithic art. Cambridge Archaeological Journal 27(1), 85-94.

Jones, A.M., A. Cochrane, C. Carter, I. Dawson, M. Díaz-Guardamino, E. Kotoula \& L. Minkin, 2015 Digital imaging and prehistoric imagery: a new analysis of the Folkton Drums. Antiquity 89, 1083-95.

Jones, A.M., M. Díaz-Guardamino \& R.J. Crellin, 2016. From artefact biographies to 'multiple objects': a new analysis of the decorated plaques of the Irish Sea region. Norwegian Archaeological Review 49(2), 113-33.

Jones, A.M. \& A. Cochrane, 2018. The Archaeology of Art. Materials, practices, affects. London: Routledge.

Jones, A.M. \& M. Díaz-Guardamino, 2019. Making a Mark. Image and process in Neolithic Britain and Ireland. Oxford: Oxbow.

Jones, A.M., M. Díaz-Guardamino, A. Gibson \& S. Cox, 2017. The Garboldisham mace head: its manufacture, date, archaeological context and significance. Proceedings of the Prehistoric Society 83, 383-94.

Jones, A.M., D. Freedman, B. O'Connor, H. Lamdin-Whymark, R. Tipping \& A. Watson, 2011. An Animate Landscape. Rock art and the prehistory of Kilmartin, Argyll, Scotland. Oxford: Windgather.

Leary, J. \& D. Field, 2010. The Story of Silbury Hill. London: English Heritage.

Loveday, R., A. Gibson, P.D. Marshall, A. Bayliss, C. Bronk Ramsey \& H. van der Plicht, 2007. The Antler Maceheads Dating Project. Proceedings of the Prehistoric Society 73, 381-92.

Marshall, P., D. Clarke, A. Sheridan, et al., 2016. Links of Noltland, Westray, Orkney Radiocarbon Dating and Chronological Modelling. (Historic England Research report 39.) https://research.historicengland.org.uk/ Report.aspx?i=15531\&ru=\%2fResults.aspx $\% 3 \mathrm{fn} \%$ 3d10\%26ry\%3d2016\%26p \%3d3

Marshall, Y. \& B. Alberti, 2014. A matter of difference: Karen Barad, ontology and archaeological bodies. Cambridge Archaeological Journal 24(1), 19-36.

McFadyen, L., 2007. Neolithic architecture and participation: practices of making at Long Barrow sites in southern Britain, in Beyond the Grave: New perspectives on barrows, ed. J. Last. Oxford: Oxbow, 22-9.

O'Sullivan, A., 1997. Last foragers or first farmers? Archaeology Ireland 40, 16-18.

Parker-Pearson, M., 2012. Stonehenge. Exploring the greatest Stone Age mystery. New York/London: Simon \& Schuster.

Parker-Pearson, M., R. Cleal, P. Marshall, et al., 2007. The age of Stonehenge. Antiquity 81, 617-39.

Raftery, J., 1970 Prehistoric coiled basketry bags. Journal of the Royal Society of Antiquaries of Ireland 100, 167-8.

Richards, C., A.M. Jones, A. Sheridan, et al., 2016. Settlement duration and materiality: formal chronological models for the development of Barnhouse, a Grooved Ware settlement in Orkney. Proceedings of the Prehistoric Society 82, 193-225. 
Robin, G., 2010. Spatial structures and symbolic systems in Irish and British passage tombs: the organization of architectural elements, parietal carved signs and funerary deposits. Cambridge Archaeological Journal 20(3), 373-418.

Schulting, R., C. Bronk Ramsey, P. Reimer, G. Eogan, K. Cleary, G. Cooney \& A. Sheridan, 2017. Dating the Neolithic human remains at Knowth, in The Passage Tomb Archaeology of the Great Mound at Knowth, eds G. Eogan \& K. Cleary. Dublin: Royal Irish Academy, 331-85.

Sheridan, A. 2014 Little and large: the miniature 'carved stone ball' beads from the eastern passage tomb under the main mound at Knowth, Ireland, and their broader significance, in Entre archéologie at écologie, une préhistoire de tous les milieu. Mélanges offerts à Pierre Petriquin, eds. R.-M. Arbogast \& A. Greffier-Richard. (Annales Littéraires de 1’Université de Franche-Comté 928; série Environnement, sociétés et archéologie 18.) Besançon: Presses universitaires de Franche-Comté, 303-14.

Sibbesson, E., 2019. Reclaiming the rotten: understanding food fermentation in the Neolithic and beyond. Environmental Archaeology. doi: 10.1080/ 14614103.2018.1563374

Smith, I.J., 1965. Windmill Hill and Avebury: Excavations by Alexander Keiller 1925-1939. Oxford: Clarendon Press.

Stevens, C.J. \& D.Q Fuller, 2012. Did Neolithic farming fail? The case for a Bronze Age agricultural revolution in the British Isles. Antiquity 86, 707-22.

Taylor, S., 2019. Down the Bright Stream. The prehistory of Woodcock Corner and the Tregurra Valley. Truro: Cornwall County Council.

Teather, A., 2011. Interpreting hidden chalk art in southern British Neolithic flint mines. World Archaeology 43(2), 230-51.

Teather, A. \& J. Kenney, 2016 New insights into the Neolithic chalk drums from Folkton (North Yorkshire) and Lavant (West Sussex). Past 83, 5-6.

Thomas, A., 2016. Art and Architecture in Neolithic Orkney: Process, temporality and context. (UHI Archaeology Institute Research series 1.) Oxford: Archaeopress.

Thomas, A., 2019. Image and process in an architectural context: decorated stonework from the Ness of Brodgar, Orkney, in Making a Mark: Image and process in Neolithic Britain and Ireland, eds A.M. Jones \& M. Díaz-Guardamino. Oxford: Oxbow, 143-64.
Valdez-Tullett, J., 2019. Design and Connectivity. The case of Atlantic rock art. (BAR International series S2932.) Oxford: BAR Publishing.

Wainwright, G. 1979. Mount Pleasant, Dorset: Excavations 1970-71. London: Society of Antiquaries of London.

Whitehouse, N.J., R.J. Schulting, M. McClatchie, et al., 2014. Neolithic agriculture on the European western frontier: the boom and bust of early farming in Ireland. Journal of Archaeological Science 51, 181-205.

Whittle, A., F. Healy \& A. Bayliss, 2011. Gathering Time: Dating the Early Neolithic causewayed enclosures of southern Britain and Ireland. 2 vols. Oxford: Oxbow.

Williams, J.L. \& A. Davidson, 1998. Survey and excavation at the Graig Lwyd Axe-Factory, Penmaenmawr, Archaeology in Wales 38, 3-21.

Williams, J.L. \& J. Kenney, 2011 A chronological framework for the Graig Lwyd axe factory: an interim scheme. Archaeology in Wales 50, 13-20.

Woodward, P. 1988. Pictures of the Neolithic: discoveries from the Flagstones House excavations, Dorchester, Dorset. Antiquity 62, 266-74.

Woodward, P. \& R.J. Smith, 1988. Survey and excavation along the route of the southern Dorchester by-pass 1986-7 - an interim note. Dorset Natural History and Archaeological Society 109, 79-89.

\section{Author biographies}

Andrew Meirion Jones is Professor of Archaeology, Stockholm University, Sweden. He has taught and written extensively on the archaeology of art, particularly rock art. His most recent books are The Archaeology of Art. Materials, practices, affects (Routledge, 2018) written with Andrew Cochrane, Making a Mark: Image and process in Neolithic Britain and Ireland (Oxbow, 2019), with Marta DíazGuardamino, and Images in the Making: Art, process, archaeology (Manchester University Press, 2020), co-edited with Ing-Marie Back Danielsson.

Marta Díaz-Guardamino is Lecturer in Archaeology at Durham University, UK. Her research interests are in European prehistory, archaeological theory, and digital technologies. She has studied prehistoric rock art, monumental sculpture and portable art from Iberia, Britain, and Ireland, including fieldwork at find spots of stelae and statue-menhirs. Her most recent book is Making a Mark: Image and process in Neolithic Britain and Ireland (Oxbow, 2019), co-authored with Andrew Meirion Jones. 